[Agr. Biol. Chem., Vol. 34, No. 7, p. 1126 1128, 1970]

\title{
A Proteinase Produced by Pseudomonas aeruginosa Isolated from Chilo suppressalis
}

Sir:

A crystalline proteinase was obtained from culture broth of Pseudomonas aeruginosa isolated from Chilo suppressalis.

Cultivation and purification were carried out as follows: Ps. aeruginosa was cultured in 2000 $\mathrm{ml}$ of glucose-bouillon medium.

The medium was contained in shaking flasks of $5000 \mathrm{ml}$ volume, which were placed on a rotary shaker and incubated at $28 \sim 30^{\circ} \mathrm{C}$ for 2 days.

The culture broth was centrifuged at 11,000 rpm and the proteinase in the supernatant solution was purified by salting out with ammonium sulfate (0.65 saturation), dialysis (against $0.001 \mathrm{M}$ tris buffer, $\mathrm{pH} 8.6$ containing $10^{-3} \mathrm{M} \mathrm{CaCl}_{2}$ for $16 \mathrm{hr}$ at $5^{\circ} \mathrm{C}$ ), acetone-calcium chloride treatment $\left(2 \% \mathrm{CaCl}_{2}\right.$ and $10 \%$ acetone; to remove the mucin-like substances) and precipitation by acetone (75\%).

The precipitate obtained was dissolved into $0.05 \mathrm{M}$ tris buffer $\mathrm{pH} 8.6$ and dialyzed against $0.001 \mathrm{M} \mathrm{CaCl}_{2}$ solution for $16 \mathrm{hr}$ at $5^{\circ} \mathrm{C}$. The

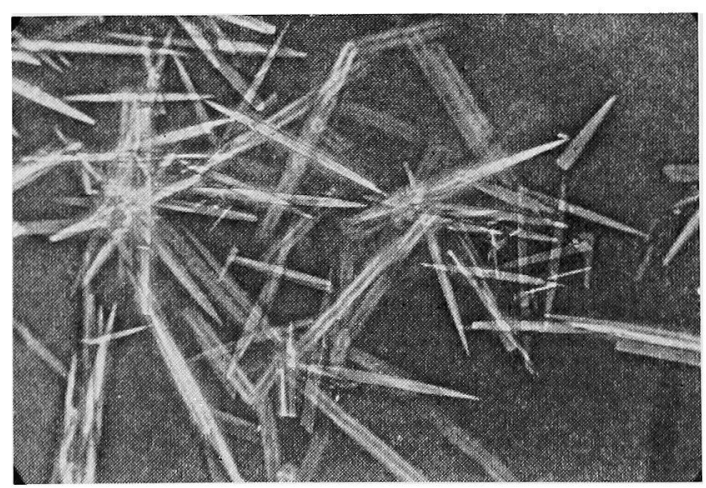

FIG. 1. Photograph $(\times 350)$ of Crystalline Proteinase from Ps. aeruginosa.

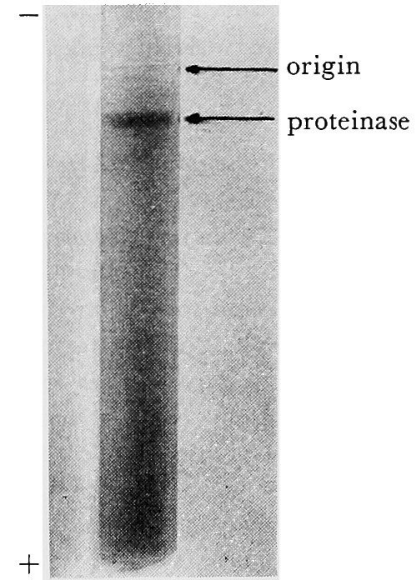

FIG. 2. Electrophoretic Homogeneity of Crystalline Proteinase (tris-HCI buffer, $\mathrm{pH} 9.4$ ).

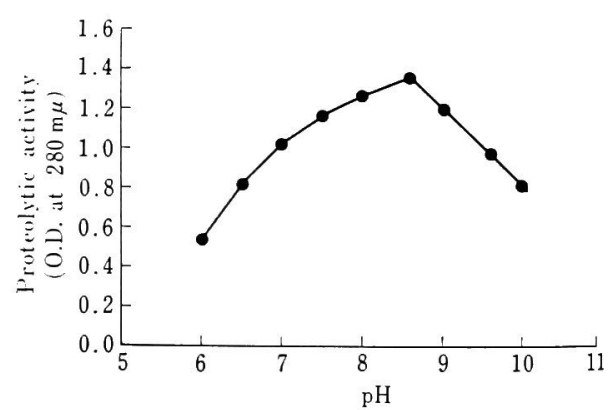

FIG. 3. Optimum pH for Proteolytic Action of the Proteinase.

The reaction mixture contained $1 \mathrm{ml}$ of $1 \%$ solution of casein at various $\mathrm{pH}$ values and $1 \mathrm{ml}$ of $0.005 \%$ solution of the enzyme in various buffer solutions. Mixtures were kept for $20 \mathrm{~min}$ at $40^{\circ} \mathrm{C}$.

After precipitation by $5 \% \circ$ trichloroacetic acid solution, optical densities at $280 \mathrm{~m} \mu$ of the supernatant solution were measured. 


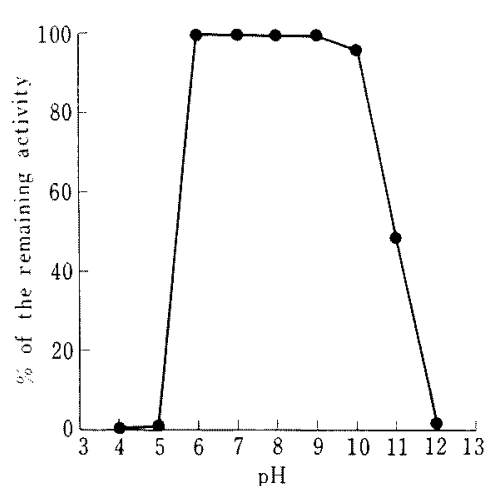

FIG. 4. Effect of $\mathrm{pH}$ on Stability of the Proteinase.

Buffer solutions used were: citrate buffer $(\mathrm{pH} 4.0$ $\sim 5.0$ ); phosphate buffer ( $\mathrm{pH} 6 \sim 8$ ); glycine-sodium hydroxide buffer $(\mathrm{pH} 9 \sim 10)$; borate buffer ( $\mathrm{pH}$ $10 \sim 12)$. To $0.8 \mathrm{ml}$ of each buffer solution, $0.2 \mathrm{ml}$ of a $0.10 \mathrm{~s}$ solution of the enzyme (in distilled water) was added and the mixture was kept at $30^{\circ} \mathrm{C}$ for $20 \mathrm{hr}$. After adjusting the $\mathrm{pH}$ to 8.6 , the final volume was made up to $5.0 \mathrm{ml}$. Proteolytic activity was determined before and after treatment, and the percentage of the activity remaining is indicated.

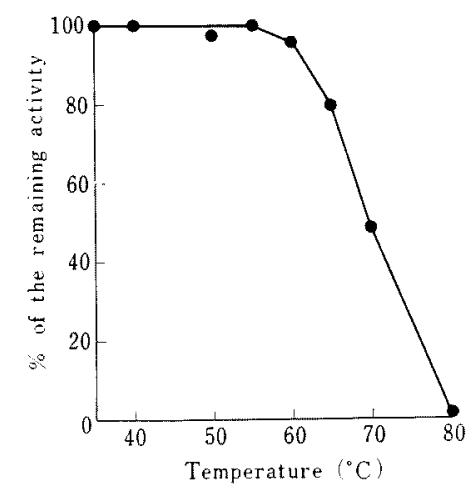

FIG. 5. Effect of Heat Treatment on Stability of the Proteinase.

To $0.8 \mathrm{ml}$ of the $0.05 \mathrm{M}$ tris buffer solution $\mathrm{pH}$ 8.6 which was preincubated at various temperatures for $10 \mathrm{~min}, 0.2 \mathrm{ml}$ of $0.01 \%$ solution of the proteinase (in distilled water) was added and kept at the respective temperatures. After $10 \mathrm{~min}$ each solution was rapidly cooled. The remaining activity was determined and the percentage of the residual activity is indicated. dialyzate was concentrated by lyophilization. Needle-like crystals were formed, as shown in Fig. 1. After recrystallization the enzyme appeared to be homogeneous on disc electrophoresis, as shown in Fig. 2.

The nature of this enzyme is as follows: the optimum $\mathrm{pH}$ of the proteolytic activity is at pH $8 \sim 9$ for casein as shown in Fig. 3.

Figures 4 and 5 show the effects of $\mathrm{pH}$ and heat treatment on the stability of this enzyme. These results show that this proteinase is stable within the $\mathrm{pH}$ range from 6 to 10 and is also stable for temperatures up to $65^{\circ} \mathrm{C}$, unlike most proteinases.

Proteins such as casein, gelatin, egg albumin, haemoglobin were easily hydrolyzed by the enzyme. Elastin was also hydrolyzed to some extent, as shown in Fig. 6. Keratinase ac-

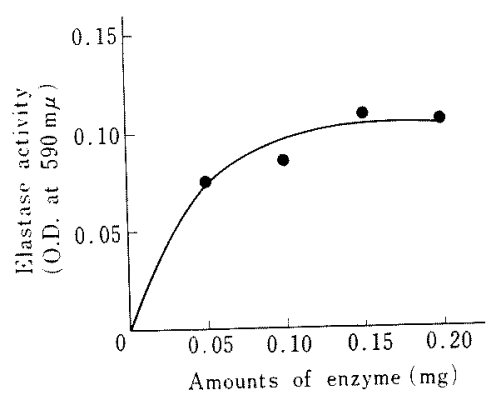

FIG. 6. Elastolytic Activity of Crystalline Enzyme.

Each reaction mixture contained $20 \mathrm{mg}$ of orcein elastin, $3 \mathrm{ml}$ of $0.05 \mathrm{M}$ tris buffer $\mathrm{pH} 8.6$ and various amounts of enzyme as shown in the figure. The reaction was carried out for $3 \mathrm{hr}$ at $40^{\circ} \mathrm{C}$ and $2 \mathrm{ml}$ of $0.5 \mathrm{M}$ phosphate buffer $\mathrm{pH} 6$ were added to the reaction mixture, which then was centrifug. ed. Optical density of the supernatant solution was read at $590 \mathrm{~m} \mu$.

tivity was determined by the partially modified method of K. Morihara et al.," that is, $50 \mathrm{mg}$ of trypsin-treated wool was suspended in $5 \mathrm{ml}$ of $0.05 \mathrm{M}$ tris buffer, $\mathrm{pH} 8.6$, containing $1 \mathrm{mg}$ of enzyme. This mixture was kept for $16 \mathrm{hr}$ at $30^{\circ} \mathrm{C}$. The value 0.145 , which is the in-

1) K. Morihara, H. Tsuzuki, T. Oka, H. Inoue and M. Ebata, J. Biol. Chem., 240, 3295 (1965). 
crease in optical densities at $280 \mathrm{~m} \mu$, was obtained. The value 0.013 , was obtained from the mixture of trypsin and wool, as determined under the conditions described above.

Neither collagenase activity nor peptidase activity on L-leucineamide were observed. However, poly-L-lysine was hydrolyzed into di-, tri-, tetra-lysine etc.

The metal-chelating agent, EDTA, and heavy metal ions such as $\mathrm{Ag}^{+}, \mathrm{Cu}^{2+}, \mathrm{Hg}^{2+}$ and $\mathrm{Pb}^{2+}$ inactivated enzymatic activity but the soybean trypsin inhibitor had no effect on the enzyme.

The molecular weight of this enzyme, as determined by gel filtration on Sephdex G-75, was about 24,000 .

Morihara et al. reported that $P$ s. aeruginosa produced three kinds of proteinases, fractions I, II and III, and that fraction III proteinase was not produced in the natural medium. ${ }^{21}$

The enzyme isolated by us seems to be most similar to the semialkaline proteinase (fraction II) designated by Morihara because of similarities in formation (even in the natural medium), in its stability for heat treatment and in its elastase activity.

However, the optimum $\mathrm{pH}$ for proteolytic

2) K. Morihara, J. Bacteriol., 88, 745 (1964). activity of this enzyme and fraction II are $\mathrm{pH}$ $8 \sim 9$ and $\mathrm{pH} \quad 7 \sim 8$, respectively. The $\mathrm{pH}$ stability relationship of this enzyme also seems to differ from that of fraction II, i.e. this enzyme has no activity below $\mathrm{pH} 5$, but fraction II retains about $70{ }^{\circ}$ activity even at $\mathrm{pH}$ $5 .^{1 \prime}$

Wool keratin was not hydrolyzed by fraction II proteinase ${ }^{13}$ but was hydrolyzed to some extent by this enzyme. Its molecular weight also seems to be different. From these results this crystalline enzyme seems to be different from enzymes such as those investigated by K. Morihara et al. ${ }^{1 \sim 31}$

The elastase activity of this enzyme was observed to vary with successive inoculations and to decrease with dialysis.

Study of these interesting phenomena is now in progress.

\section{Shigeo OGINo \\ Hiroo WADA \\ Heihachiro MATSUI}

Research Department, Pharmaceuticals Division of Sumitomo Chemical Co., Ltd., Takarazuka,

Hyogo Prefecture

Received April:23, 1970

3) K. Morihara, Biochim. Biophys. Acta, 73, 113 (1963). 